\title{
Practice of Nursing Care for Central Venous Catheter Among Icus Nurses in Private Tertiary Care Hospital Peshawar, KP
}

\author{
Muslim Shah*, Muhammad Qasim, Fazalhadi, Zeeshanwahab, Tajuddin and Abdul shakoor \\ Rehman College of Nursing Peshawar, Pakistan
}

Submission: April 18, 2017; Published: June 07, 2017

*Corresponding author: Muslim Shah, Assistant Professor, Rehman College of Nursing Peshawar, Pakistan, Tel: +254-20-366-26;

Email: muslimshah266@gmail.com

\begin{abstract} KP.

Objective: To identify practices of nurses for central venous catheter care in intensive care units in private tertiary care hospitalPeshawar,

Background: Central venous catheter is important in the management of intensive care unit patients, but has serious complications which worsen the patients' condition, prolong hospitals stays, and increase the cost of care. Standard guidelines for center venous catheter care are available, but it is unknown how widely these are in practice in the intensive care units.
\end{abstract}

Methodology: A descriptive cross-sectional study was conducted among ICUs nurses in private tertiary care hospital in Peshawar. Participants were selected randomly, and the data were collected through Self-developed questionnaire. The practice of nurses regarding central venous catheter care questionnaires were distributed among nurses of intensive care units.

Result: Out of fifty (50) participants the gender distribution was fifty percent each. The mean knowledge level of intensive care unit nurses was $73.65 \%$ with standard deviation $10.671 \%$. The independent sample test ( $t$ test) was applied to identify the association between gender and practice, significant result obtained with p-value was 0.038 .

Conclusion: As the mean score in knowledge part was $73.65 \%$. So there is need to increase awareness about standard precaution for center venous catheter care among ICUs nurses to enhance Nurses practice and improve patient care.

Keywords: Central venous catheter; Evidence based practice; Infection; Intensive care unit; nursing

Abbreviations: ICU: Intensive Care Unite; CVC: Central Venous Catheter; CR-BSI: Catheter Related Blood Stream Infection; CDC: Centers for Disease Control \&Preventions; PPE: Personnel Protection Equipment

\section{Background}

Central venous catheter is commonly used vascular access in patients with hemodialysis; CVC used to associate with catheter related blood stream infection because of skin breaks darning insertion. There were 148 bacteremia incidences recognized in 102 patients. The rate of CRBSI was 0.52 per 1000 patient per days [1].

According to Mlinar [2] that Central venous catheter is necessary in intensive care units. These are used for large quantity of liquids and medication which damage peripheral veins. Furthermore, these are also used for blood transfusions, taking blood sample, monitoring hemodynamic status of critically ill patients.

The use of CVC is associated with various mechanical complications such as arterial puncture, pneumothorax, mediastinal hematoma and injury of adjacent nerves is ranged from $0-12 \%$. While infectious complications or infection at local insertion site e.g. thrombophlebitis and endocarditis is approximately 65\%. Catheter related infection, 30\% from contaminated hub, and 5\% from other pathway [3].

The use of CVCs might be leads to different complications such as morbidity, mortality, and catheter-related blood stream infections (CR-BSI) as well as health care costs. The different international health care agencies such as Healthcare Improvement (2011), WHO (2012), and US Centers for Disease Control and Prevention (CDC) have targeted it as a significant patient's safety issues [4].

According to Ullman et al. [4] in recent times critical care study reported an incidence of between 1 to 5.5 per 1000 catheter- 
days. The most commonly reported nosocomial infection in pediatrics ICUs, and the Children are more susceptible, with CRBSIs.

A study was conducted in Calabria region (Italy) among health care workers. The correct answer about the knowledge of physicians and nursesranged 43\%-72\%. This study was conducted to determine nurse's knowledge of guideline for prevention of CRBSI among 3,405 ICUs nurses from European country the mean test knowledge of score is $44.4 \%$. The overall level of nurses with recommended practice during CVC insertion in present study was considered low [5].

There are certain challenges that are faced by the ICUs nurses in care of central venous catheter. In ICUs, majority of patients has a central venous catheter for intravascular monitoring, or the administration of fluid, medication and nutrients. Central venous catheters break the body's first line of defense (the skin). So it increases the risk of catheter related infection, which is estimated 200,000 cases occur worldwide each year [6].

A study was conducted in Pakistan at Rawalpindi and Abbottabad, the result showed that catheter related infection rate was $20 \%$, while in India catheter related infection rate show $27.77 \%$ [3]. The purpose of this study was to explore practice of nurses in intensive care unit regarding CVC care in private tertiary care hospital. The study may also calculate the current practice of CVC care.

\section{Methodology}

Study Design: The research design used for this study was a descriptive cross sectional quantitative research design. Cross sectional design is best use when the researcher is interested to gather the information at one point in time, it provides a snapshot of the population.

Population: The study population was all those nurses working in private tertiary care hospital ICUs and were providing care to CVC patients.

Sample and Sampling: Fifty ICUs nurses were selected by using random sampling technique. By using this method, each member of the population has an equal chance to be selected for the study.

The sample size was minimized due to lack of budget for the project, and limited time for data collection.

\section{Inclusion Criteria}

All those nurses, who were working in ICU with at least one year experience, and those who performed central venous catheter care.

\section{Data Collection Tool}

Self-developed questionnaire was used for data collection. The questionnaire was consisting of 16 questions regardingpractice of nursing care for central venous catheter among ICUs nurses.

\section{Ethical Considerations}

Approval for the study was taken from the hospital Director Medical Services (DMS). A well-defined informed consent was presented and explained to each participant to get his/ her agreement as participant. Anonymity was maintained anddata was kept locked under password and only primary data collectors and supervisor had access. Confidentiality was maintained throughout the study.

\section{Data Analysis}

Statistical analysis was performed using the statistical package for social sciences (SPSS) version 22. Continuous data was displayed as the mean \pm standard deviation (SD), while the categorical and nominal was presented as frequencies and percentages. For qualification scale chi square test was applied and a value of $\mathrm{p}<0.005$ was considered significant. For comparison of group mean $t$ test and ANOVA was applied.

\section{Results}
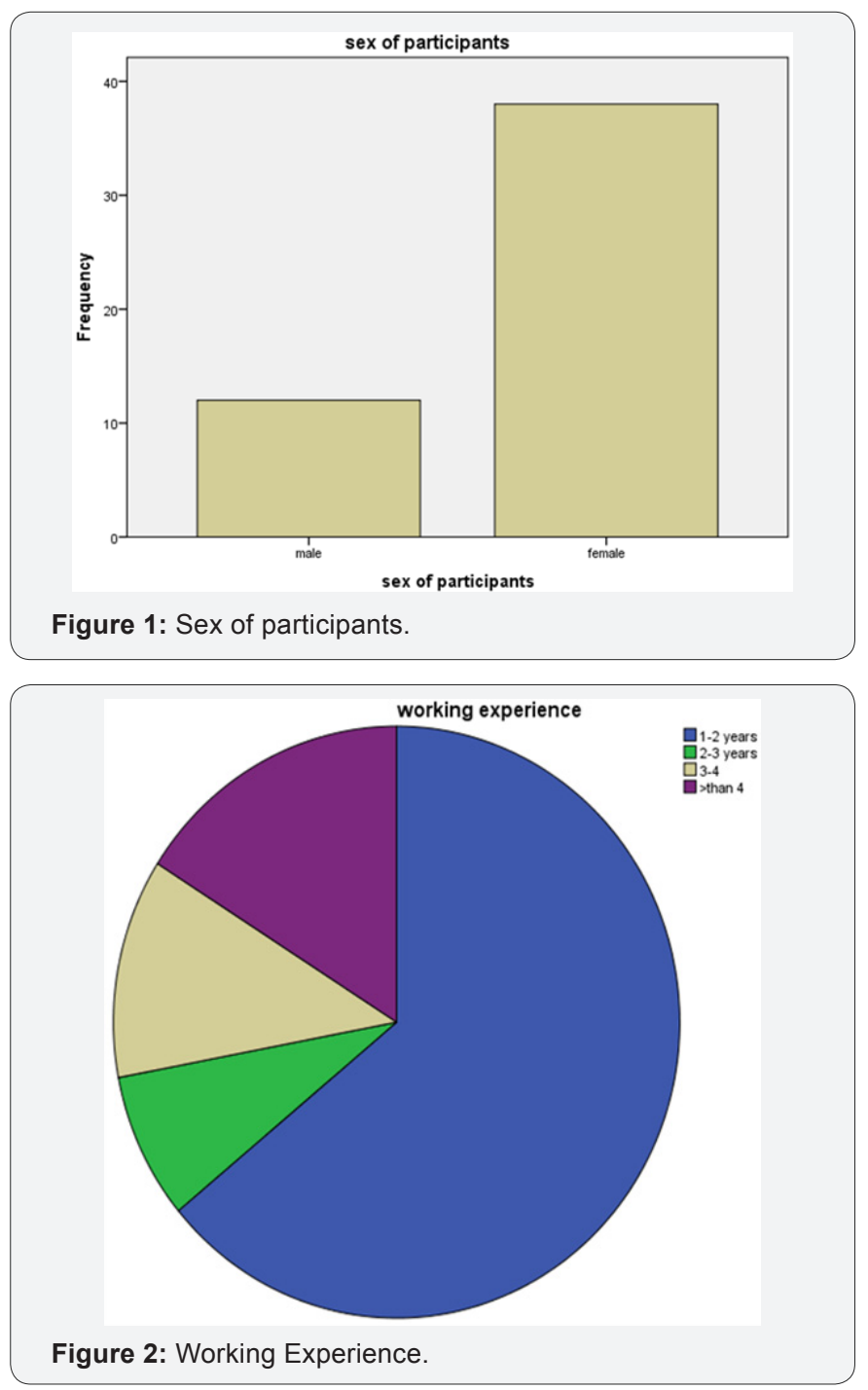

The study consisted of 50 participants, in which 12 (24\%) were male, $36(76 \%)$ were female; age range was from 19-36 
with mean 73.65, and SD 10.671(Figure 1,2). 50 participants' age was from 19-36 years. In this 1-2 year experience participants were $64 \%$, 2-3 year participants were $8 \%, 12 \%$ were $3-4$ years, more than 4 years participant were $16 \%$. Further description is given in (Figure 3,4).

Qualification level of the nures were, 3 years diploma 84\%, BScN were $12 \%$ and other (mph, midwifery and technicians) were $4 \%$, further description is given in Table 1 .

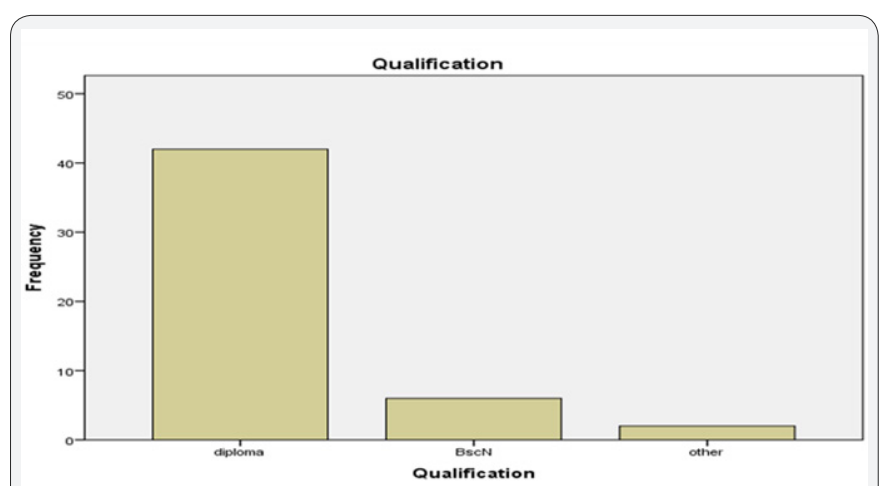

Figure 3: The overall work experience between the participants were calculated in percentage where the study revealed that the mean practice among ICU nursing regarding CVC care was $73.65 \%$ with the SD of $10.67 \%$.

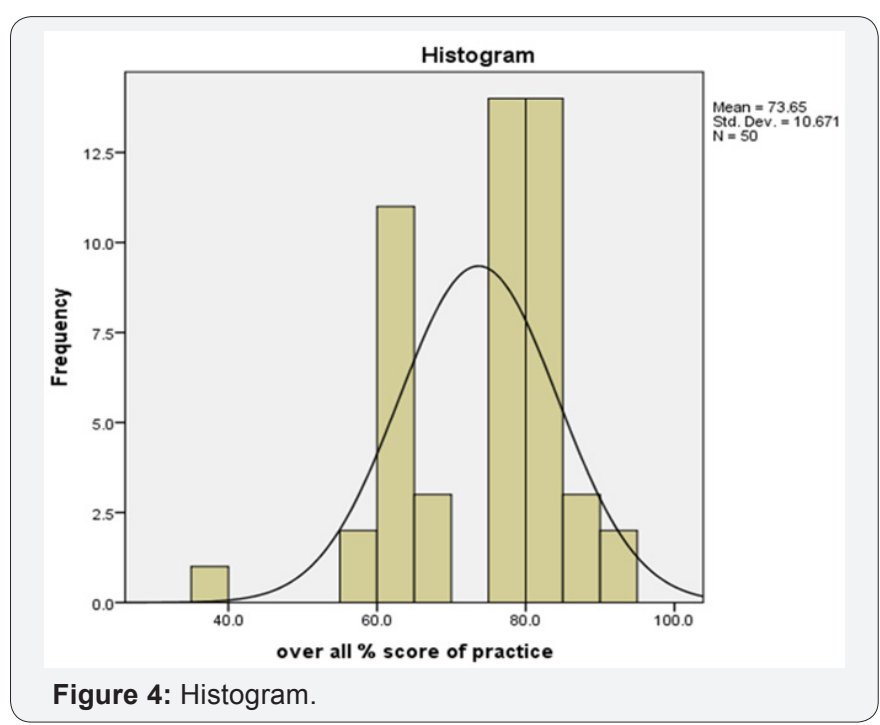

Table 1: Different variables show in the form of frequency and percentage.

\begin{tabular}{|c|c|c|}
\hline Variables & Frequency $(\mathbf{n})$ & $\mathbf{N}(\%)$ \\
\hline Sex & 50 & 100 \\
\hline Men & 12 & 24 \\
\hline Female & 38 & 76 \\
\hline Experience & Frequency & $\mathbf{N} \%$ \\
\hline 1-2 years & 32 & $64 \%$ \\
\hline 2-3 years & 4 & $8 \%$ \\
\hline 3-4 years & 6 & $12 \%$ \\
\hline Above 4 years & 8 & $18 \%$ \\
\hline
\end{tabular}

\begin{tabular}{|c|c|c|}
\hline Qualification & Frequency & N\% \\
\hline Diploma & 42 & $84 \%$ \\
\hline BScN & 6 & $12 \%$ \\
\hline Others & 2 & $4 \%$ \\
\hline
\end{tabular}

Table 2: Each question result was shown.

\begin{tabular}{|c|c|c|c|c|}
\hline S.NO & Question & Yes & no & $\begin{array}{l}\text { Don't } \\
\text { know }\end{array}$ \\
\hline 1 & $\begin{array}{l}\text { Do you use standard precaution, for } \\
\text { the insertion of CVCs? }\end{array}$ & $98 \%$ & $2 \%$ & \\
\hline 2 & $\begin{array}{l}\text { Do you confirm patient's diseases } \\
\text { before central venous catheter } \\
\text { insertion to make sure no contra- } \\
\text { indication for central venous } \\
\text { catheter insertion? }\end{array}$ & $94 \%$ & $4 \%$ & $2 \%$ \\
\hline 3 & $\begin{array}{c}\text { Do you perform hand washing } \\
\text { during central venous catheter (CVC) } \\
\text { care? }\end{array}$ & $92 \%$ & $8 \%$ & \\
\hline 4 & $\begin{array}{l}\text { Do you wear gloves while changing } \\
\text { the dressing of patient with central } \\
\text { venous Catheters? }\end{array}$ & $98 \%$ & $2 \%$ & \\
\hline 5 & $\begin{array}{l}\text { Do you inspect and compare veins } \\
\text { on both hands (site) for selection of } \\
\text { best vein before insertion of central } \\
\text { venous catheter? }\end{array}$ & $82 \%$ & $10 \%$ & $8 \%$ \\
\hline 6 & $\begin{array}{l}\text { Do you disinfect the catheter } \\
\text { insertion site with standard } \\
\text { disinfectant solution? }\end{array}$ & $86 \%$ & $14 \%$ & \\
\hline 7 & $\begin{array}{c}\text { Do you apply standard transparent } \\
\text { dressing on central venous catheter } \\
\text { insertion site? }\end{array}$ & $96 \%$ & $4 \%$ & \\
\hline 8 & $\begin{array}{l}\text { Do you change the dressing of } \\
\text { central venous catheter insertion } \\
\text { site On daily basis? }\end{array}$ & $74 \%$ & $26 \%$ & \\
\hline 9 & $\begin{array}{l}\text { Do you inspect the catheter site daily } \\
\text { for signs of infection? }\end{array}$ & $98 \%$ & $2 \%$ & \\
\hline 10 & $\begin{array}{l}\text { Do you administer intravenous } \\
\text { antibiotic prophylactically in daily } \\
\text { routine? }\end{array}$ & $80 \%$ & $\begin{array}{l}12 \% \\
\text { correct }\end{array}$ & $8 \%$ \\
\hline 11 & $\begin{array}{c}\text { Do you replace Central venous } \\
\text { catheter (CVCs) after every seven } \\
\text { days? }\end{array}$ & $28 \%$ & $68 \%$ & $2 \%$ \\
\hline 12 & $\begin{array}{l}\text { Do you change needleless } \\
\text { connectors on every } 72 \text { hours? }\end{array}$ & $46 \%$ & $52 \%$ & $2 \%$ \\
\hline 13 & $\begin{array}{c}\text { Do you use topical antibiotic } \\
\text { ointment or creams on insertion } \\
\text { sites? }\end{array}$ & $58 \%$ & $\begin{array}{l}40 \% \\
\text { correct }\end{array}$ & $2 \%$ \\
\hline 14 & $\begin{array}{l}\text { Do you have a standard guideline in } \\
\text { ICUs for CVC care? }\end{array}$ & $90 \%$ & $8 \%$ & $2 \%$ \\
\hline 15 & $\begin{array}{l}\text { Do you cap Central venous catheter } \\
\text { stopcocks when not in use? }\end{array}$ & $92 \%$ & $8 \%$ & \\
\hline 16 & $\begin{array}{c}\text { Do you remove central venous } \\
\text { catheters if the patients develop } \\
\text { signs of infection or malfunctioning } \\
\text { catheter? }\end{array}$ & $94 \%$ & $4 \%$ & $2 \%$ \\
\hline
\end{tabular}

In result the independent sample test ( $\mathrm{t}$ test) applied to identify the association between gender and practice, significant result obtained with p-value was 0.038 (Table 2). One way 
anova with post hoc test was applied to identify the association between qualification and experience to practice score that was not significant.

\section{Discussion}

Nurses play an important role in prevention of CVC complication or CR-BSI through applying standard guideline such as maintaining aseptic environment during insertion of CVC. During insertion of CVC,nurses should use sterilized instrument with aseptic technique, best practice need for prevention of central venous catheter related infection CVCRI during insertion or care of CVC. The overall level of nurses complains with recommended practice is considered low [5], however in this study,results showed that nurse used standard guideline for CVC care. The standard deviation is 10.671 while mean is 73.65 .

According to Kalender [7] that Centers for Disease Control \&Preventions (CDC) recommended chlorhexidine would be first preference for skin antiseptic. While povidone-iodine and $70 \%$ alcohol should be use only when there is an absence or contraindication of chlorhexidine. Then alcohol+ chlorhexidine should be used combine to decrease the risk of CVC-RI. In this study $86 \%$ nurses used standard antiseptic solution before insertion of CVC, while 14\% nurses don't use standard antiseptic solution in practice.

According to Stephen (2011) a randomized controlled trials showed that when prophylactically intravenous antibiotic given to neonate, cancer patient or high risk of immunosuppressed patients, it reduces catheter related infection and sepsis. Similarly, in this study $80 \%$ ICUs nurses also administered intravenous antibiotic prophylacticallyroutinely.

Furthermore, according to Kalender [7] that gauze dressing should be changed every day if there was no leakage, or loosening while transparent dressings change every seven days. In this study $96 \%$ nurses used standard transparent dressing on central venous catheter insertion site, and 74\% nurses changed transparent on daily basis.

\section{Conclusion}

Handling and monitoring CVC is very important and responsible aspect of the nurses' work. CVC infection is a complication that can be prevented by high quality nursing care of CVC. Mostly ICUs nurses are doing practice for the CVC care, but they are not aware about standard guideline ofCenters for Disease Control and Prevention (CDC) 2011. Therefore, nurses might not follow evidence based practice during CVC care. In addition the nursing manager and infection control team should plan for training program based on evidence based practice. In fact, training program should be focused not only learning content, but also on the importance to follow recommendations for the patient such as discomfort, phlebitis additional costs and increase length of stay.

\section{References}

1. Salim I, Kadium M (2013) An Education Intervention to Improve Nurses' Knowledge to Reduce Catheter-Related Bloodstream Infection in Hemodialysis Unit. International Journal of Science and Research (IJSR).

2. Mlinar S, Malnarsic RR (2012) Knowledge of nursing students about central venous catheters. Vojnosanit Pregl 69(4): 333-339.

3. Ahmad B, khan MI, Beg AM (2016) Frequency of centeral venous cathter related infections and their culture and sensitive pattern. Journal of Islamabad medical and dental college 5(2): 63-66.

4. Ullman A, Long D, Rickard C (2013) Prevention of central venous catheter infection: a survey of pediatric ICU nurses, knowledge and practice. Nurse Educ Today 34(2): 202-207.

5. Alkubati SA, Ahmad N, Muhamed O, Fayed A, Asfour H (2015) Health care workers' knowledge and practice regarding the prevention of central venous catheter-relater infection. Am J Infect Control 43(1): 26-30.

6. Rickard C, Courtney M, Webster J (2004) Central venous catheters: a survey of ICU practices. J Adv Nurs 48(3): 247-256.

7. Kalender N (2015) A literature review and recommendation for clinical practice. Nursing study about central venous catheter 8(2): 461 .

Your next submission with Juniper Publishers will reach you the below assets

- Quality Editorial service

- Swift Peer Review

- Reprints availability

- E-prints Service

- Manuscript Podcast for convenient understanding

- Global attainment for your research

- Manuscript accessibility in different formats

( Pdf, E-pub, Full Text, Audio)

- Unceasing customer service

Track the below URL for one-step submission https://juniperpublishers.com/online-submission.php 